\title{
Intramolecular C-N Bond Formation via Thermal Arene C-H Bond Activation Supported by Au(III) Complexes
}

\author{
Julianna Mruk ${ }^{1}$, Agata J. Pacuła-Miszewska ${ }^{1}$, Leszek Pazderski ${ }^{2}$, Joanna Drogosz-Stachowicz ${ }^{3}$, Anna E. Janecka ${ }^{3}$ \\ and Jacek Ścianowski ${ }^{1, * *(1)}$ \\ 1 Department of Organic Chemistry, Faculty of Chemistry, Nicolaus Copernicus University, 7 Gagarin Street, \\ 87-100 Torun, Poland; julianna@doktorant.umk.pl (J.M.); pacula@umk.pl (A.J.P.-M.) \\ 2 Department of Analytical Chemistry and Applied Spectroscopy, Faculty of Chemistry, Nicolaus Copernicus \\ University, 7 Gagarin Street, 87-100 Torun, Poland; leszek.pazderski@umk.pl \\ 3 Department of Biomolecular Chemistry, Faculty of Medicine, Medical University of Lodz, Mazowiecka 6/8, \\ 92-215 Lodz, Poland; joanna.drogosz@stud.umed.lodz.pl (J.D.-S.); anna.janecka@umed.lodz.pl (A.E.J.) \\ * Correspondence: jsch@umk.pl
}

\section{check for}

updates

Citation: Mruk, J.;

Pacuła-Miszewska, A.J.; Pazderski, L.; Drogosz-Stachowicz, J.; Janecka, A.E.; Ścianowski, J. Intramolecular C-N Bond Formation via Thermal Arene C-H Bond Activation Supported by $\mathrm{Au}(\mathrm{III})$ Complexes. Materials 2021, 14, 1676. https://doi.org/10.3390/ ma14071676

Academic Editors: Daniela Iannazzo and Víctor A. de la Peña O'Shea

Received: 2 February 2021

Accepted: 23 March 2021

Published: 29 March 2021

Publisher's Note: MDPI stays neutral with regard to jurisdictional claims in published maps and institutional affiliations.

Copyright: (c) 2021 by the authors. Licensee MDPI, Basel, Switzerland. This article is an open access article distributed under the terms and conditions of the Creative Commons Attribution (CC BY) license (https:/ / creativecommons.org/licenses/by/ $4.0 /)$.

\begin{abstract}
One of the main tactics to access $\mathrm{C}-\mathrm{N}$ bonds from inactivated $\mathrm{C}-\mathrm{H}$ functionalities is direct transition metal-supported aminations. Due to the often harsh reaction conditions, the current goal in the field is the search for more mild and sustainable transformations. Herein, we present the first solvent-free thermally induced $\mathrm{C}-\mathrm{N}$ bond formation driven by $\mathrm{Au}(\mathrm{III})$ salts. The general structure of the products was confirmed by ${ }^{1} \mathrm{H},{ }^{13} \mathrm{C},{ }^{15} \mathrm{~N}$ NMR, TGA-DTA and ATR/FT-IR analysis. Additionally, all derivatives were tested as catalysts in a three-component coupling reaction between phenylacetylene, benzaldehyde and piperidine and as anticancer agents on HL-60 and MCF-7 cell lines.
\end{abstract}

Keywords: C-H activation; C-N bond formation; antioxidant activity; antiproliferative activity

\section{Introduction}

Direct functionalization of an inactive and highly stable $\mathrm{C}-\mathrm{H}$ bond, feasible in mild reaction conditions, remains a challenge in the field of organometallic reactions. Over the years, transition metals such as $\mathrm{Pd}, \mathrm{Pt}, \mathrm{Rh}$, Ir and Ru have been widely utilized as metal centers in catalytic systems and have enabled the design of various transformation protocols [1,2]. Among various transition metals $\mathrm{Au}$ also started to be recognized as a promising constituent in organic synthesis. Particularly $\mathrm{Au}(\mathrm{III})$, isoelectronic to the widely used $\mathrm{Pd}(\mathrm{II})$ and $\mathrm{Pt}(\mathrm{II})$, can be easily applied in constructing analogous metal catalysts, additionally more available due to its higher abundance [3]. Gold complexes had been applied in numerous reactions enabling the formation of new $C-C$ and $C-X(X=O, N, S$, halogen) bonds [4-8]. Most of these procedures rely on the Lewis acidity of $\mathrm{Au}$, resulting in the activation of carbon-carbon $\pi$-bonds towards nucleophiles. More recently, the ability of $\mathrm{Au}(\mathrm{I}) / \mathrm{Au}(\mathrm{III})$ catalytic systems to perform cross-coupling transformations and arene $\mathrm{C}-\mathrm{H}$ activation were also highlighted. $\mathrm{Au}(\mathrm{III})$, in the form of $\mathrm{AuBr}_{3}, \mathrm{HAuCl}_{4}$ and $\mathrm{NaAuCl}_{4}$ can be efficiently applied in nitrogen-assisted $\mathrm{C}_{\mathrm{ary}}-\mathrm{H}$ activation through cyclometalation [9-11]. Cleavage and functionalization of the $\mathrm{C}-\mathrm{H}$ bonds can be facilitated by prior nitrogen functional group coordination that directs the regiochemistry of the process. Several examples of $\mathrm{N}$-donor ligands, like monodentate phenylpyridines [12], $N, \mathrm{C}, \mathrm{N}$-tridentate 1,3(2-pirydyl) benzene [13] and $N$-confused porphirines [14], can undergo facile cycloauration to form various stable cyclometalated $\mathrm{Au}(\mathrm{III})$ species [10]. In this process, the nitrogen donor first coordinates the $\mathrm{Au}$ center to form the $\sigma$-complex 1 . Further intramolecular $\mathrm{C}_{\text {aryl }}-\mathrm{H}$ bond activation leads to the metallacycle 2 . If the nitrogen donor is also the coupling partner towards the pseudo-nucleophilic metallated carbon, it enables, through the reductive elimination of $\mathrm{Au}(\mathrm{I})$ species, a straightforward transformation of a sp $\mathrm{sp}^{2} \mathrm{C}-\mathrm{H}$ bond to a sp ${ }^{2} \mathrm{C}-\mathrm{N}$ bond (structure 3 , Scheme 1 ). 


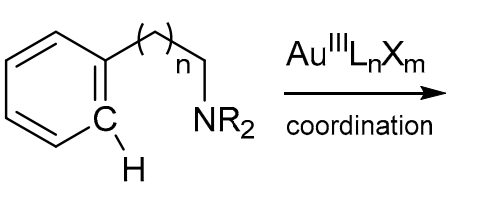

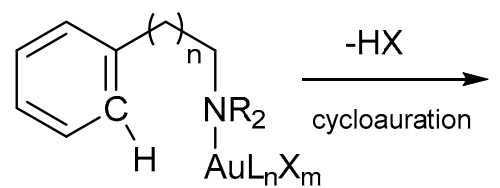
1

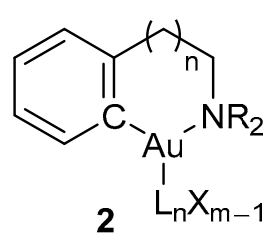

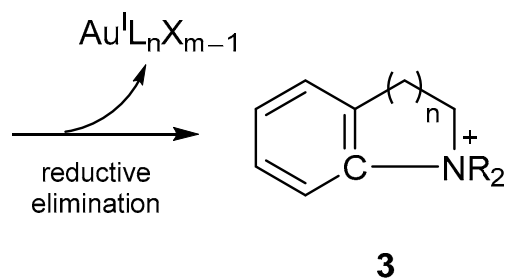

Scheme 1. $\mathrm{C}_{\text {aryl }}-\mathrm{N}$ bond formation through cyclometallation.

An ideal direct $\mathrm{sp}^{2} \mathrm{C}-\mathrm{N}$ bond formation is one that can be performed through a coupling of C-H with $\mathrm{N}-\mathrm{H}$ with no pre-activation of either reaction partner, defined as a cross dehydrogenative coupling (CDC) amination [15]. Until now, several research groups constructed various $\mathrm{N}$-heterocycles by intramolecular $\mathrm{CDC}$ amination using $\mathrm{Cu}, \mathrm{Pd}$ or $\mathrm{Ru}$ catalysts (Scheme 2) [16-20].

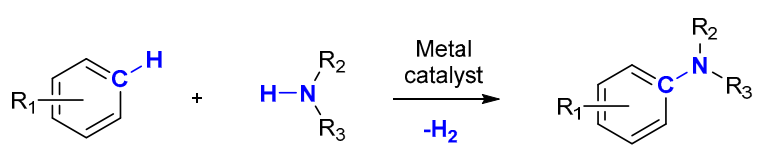<smiles>COC(=O)n1c2ccccc2c2ccccc21</smiles>

Buchwald, 2005 $\mathrm{Pd}^{0} / \mathrm{Pd}^{\prime \prime}$<smiles>c1ccc2c(c1)nc1ccccn12</smiles>

Zhang, 2010 $\mathrm{Pd}^{0} / \mathrm{Pd}^{\prime \prime}$<smiles>c1ccc(-c2cc(-c3ccccc3)n(-c3ccccc3)n2)cc1</smiles>

Rao, 2012 $\mathrm{Ru}^{\mathrm{R}} / \mathrm{Ru}^{\prime \prime}$
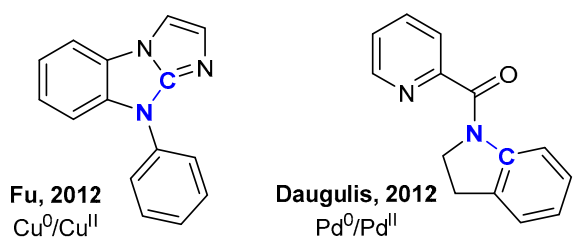

Scheme 2. Examples of heterocycles obtained by $\mathrm{sp}^{2} \mathrm{C}-\mathrm{sp}^{2} \mathrm{~N}$ bond construction through $\mathrm{CDC}$ amination.

In this field, the applicability of Au-catalytic systems is limited and just starting to develop. Recently, Kim and co-workers [21] presented the first direct intramolecular sp ${ }^{2} \mathrm{C}-\mathrm{sp}^{2} \mathrm{~N}$ bond formation through carbene-induced reductive elimination from two $\mathrm{Au}(\mathrm{III})$ dichloride organometallics containing $\mathrm{C}\left(2^{\prime}\right)$-deprotonated, $\mathrm{N}(1), \mathrm{C}\left(2^{\prime}\right)$-chelating 2-benzylpyridine* or 2-benzoylpyridine ${ }^{*}$ anionic ligands ([ $\mathrm{Au}^{\mathrm{III}}$ (2-benzylpyridine $\left.\left.{ }^{*}\right) \mathrm{Cl}_{2}\right]$ $4 \mathbf{x} ;\left[\mathrm{Au}^{\mathrm{III}}\left(2\right.\right.$-benzoylpyridine $\left.\left.\left.{ }^{*}\right) \mathrm{Cl}_{2}\right]-4 \mathbf{y}\right)$. Heating the $4 \mathbf{x}$ or $4 \mathbf{y}$ metallacycles with various imidazolium-derived cations 5 (1,3-bis(2,4,6-trimethylphenyl)-, 1,3-bis(2,6-diisopropylphenyl)-, 1,3-bis(4-hydroxophenyl)-, 1,3-di-tert-butyl- and 1,3-dicyclohexyl imidazolium; all in the chloride or tetrafluoroborate salts) in 1,4-dioxane and upon the presence of $\mathrm{NBu}_{4}(\mathrm{acac})$, resulted in the formation of heterocyclic cations $6 \mathbf{x}$ or $6 \mathbf{y}$ (with acac ${ }^{-}$counterions) and the respective $\mathrm{Au}(\mathrm{I})$-(imidazol-2-ylidene) monochloride complexes 7, with simultaneous $\mathrm{HCl}$ elimination (Scheme 3). The X-ray structure of polymeric $(6 y){ }_{n}{ }^{n+}\left[\mathrm{AgCl}_{2}\right]_{n}{ }^{\mathrm{n}-}$ salt (ROFWUH) [22], as well as the ${ }^{1} \mathrm{H}$ and ${ }^{13} \mathrm{C}$ NMR spectra (but not the ${ }^{15} \mathrm{~N}$ NMR ones) of $6 \mathbf{x}$ and $6 \mathbf{y}$ were also reported [21].<smiles>[X]c1ccccc1N(Cl)Cl</smiles>

$4 \mathbf{x}, \mathrm{X}=\mathrm{CH}_{2}$ $4 y, X=C=O$<smiles></smiles>

5

$$
\begin{aligned}
\mathbf{R}= & 2,4,6-\mathrm{CH}_{3}-\mathrm{Ph} \\
& 2,6-\mathrm{Pr}-\mathrm{Ph} \\
& 4-\mathrm{OH}-\mathrm{Ph} \\
& \text {-tert-Bu } \\
& \text {-cyclohexyl }
\end{aligned}
$$

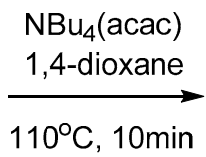<smiles>[X]c1ccccc1-[n+]1[c-]cccc1</smiles>

$6 x, X=\mathrm{CH}_{2}$

$6 y, X=C=O$<smiles></smiles>

7

Scheme 3. Example of $\mathrm{sp}^{2} \mathrm{C}-\mathrm{sp}^{2} \mathrm{~N}$ bond construction through $\mathrm{CDC}$ amination (carbene-induced reductive elimination) in Au-catalytic systems. 


\section{Materials and Methods}

2.1. General

$\mathrm{HAuCl}_{4}$ was prepared by dissolving gold in aqua regia, while $\mathrm{NaAuCl}_{4}$ by the reaction of $\mathrm{HAuCl}_{4}$ with $\mathrm{NaHCO}_{3}$, followed by solvent evaporation. Benzaldehyde was purchased from Ubichem, phenylacetylene from TCI, and all other reagents and solvents from SigmaAldrich. Column chromatography was performed using Merck 40-63D 60 A silica gel.

Elemental analyses were performed on a Vario MACRO CHN analyzer (Elementar Analysensysteme $\mathrm{GmbH}$, Langenselbold, Germany). Melting points were measured with a Büchi Tottoli SPM-20 heating unit (Büchi Labortechnik AG, Flawil, Switzerland) and remained uncorrected. Thermogravimetric analysis was performed on SDT 2960 thermoanalizer (TA Instruments, New Castle, DE, USA). Far-IR spectra were measured on FT-IR Vertex 70V spectrometer (Bruker, Karlsruhe, Germany). Mass spectrum was collected on a Shimadzu High Performance Liquid Chromatograph/Mass Spectrometer LCMS-8030 (Shimadzu, Kyoto, Japan). ${ }^{1} \mathrm{H}$ and ${ }^{13} \mathrm{C}$ NMR spectra (including ${ }^{1} \mathrm{H}_{-}{ }^{13} \mathrm{C}$ HSQC and HMBC) were measured by a Bruker Avance III $400 \mathrm{MHz}$ NMR spectrometer, while the ${ }^{1} \mathrm{H}-{ }^{15} \mathrm{~N}$ $\mathrm{HMBC}$ ones by a Bruker Avance III $700 \mathrm{MHz}$ spectrometer, at 295-300 K, in $\mathrm{CDCl}_{3}$ or DMSO- $\mathrm{d}_{6}$ (Bruker, Karlsruhe, Germany). The ${ }^{1} \mathrm{H}$ and ${ }^{13} \mathrm{C}$ chemical shifts were referenced to TMS (with residual ${ }^{1} \mathrm{H}$ and ${ }^{13} \mathrm{C}$ solvent signals as primary references- $\mathrm{CDCl}_{3}: 7.24 \mathrm{ppm}$ and 77.2 ppm; DMSO- $\mathrm{d}_{6}: 2.50 \mathrm{ppm}$ and $39.5 \mathrm{ppm}$ ), while those of ${ }^{15} \mathrm{~N}$ - to external neat nitromethane $\left(\mathrm{CH}_{3} \mathrm{NO}_{2}\right)$. All NMR spectra were carried out using ACD/NMR Processor Academic Edition (product version 12.01), and the most important are presented in Supplementary Materials (Figures S1-S43).

Human promyelocytic leukemia cell line (HL-60) and a solid tumor-derived human breast adenocarcinoma cell line (MCF-7) were obtained from the European Collection of Cell Cultures (ECACC, Porton Down, UK). Leukemia cells were grown in RPMI 1640 plus GlutaMax I medium (Gibco/Life Technologies, Carlsbad, CA, USA). MCF-7 cells were maintained in Minimum Essential Medium Eagle (Sigma Aldrich, St. Louis, MO, USA) and supplemented with $2 \mathrm{mM}$ glutamine and Men Non-essential amino acid solution (Sigma Aldrich, St. Louis, MO, USA). Both media were supplemented with 10\% heatinactivated fetal bovine serum (Biological Industries, Beit-Haemek, Israel) and antibiotics (100 U/mL penicillin and $100 \mu \mathrm{g} / \mathrm{mL}$ streptomycin) (Sigma-Aldrich, St. Louis, MO, USA). The nontumorigenic mammary gland/breast MCF-10A cell line was purchased from the American Type Culture Collection (ATCC). For MCF-10A cells MEGM Mammary Epithelial Bullet Kit was used. Cells were maintained at $37{ }^{\circ} \mathrm{C}$ in a $5 \% \mathrm{CO}_{2}$ humidified atmosphere and were grown until $80 \%$ confluent.

\subsection{Procedures}

2.2.1. General Procedure for the Synthesis of Ligands 8-15

This general procedure can be exemplified by the synthesis of 8 . A mixture of 2bromopyridine $(5.0 \mathrm{mmol})$, benzenethiol $(5.0 \mathrm{mmol})$ and $\mathrm{K}_{2} \mathrm{CO}_{3}(10.0 \mathrm{mmol})$ in dimethyl sulfoxide (DMSO; $4 \mathrm{~mL}$ ) was stirred at $110^{\circ} \mathrm{C}$ for $24 \mathrm{~h}$. It was cooled to room temperature, diluted with water $(10 \mathrm{~mL})$ and extracted with dichloromethane $(4 \times 5 \mathrm{~mL})$. The organic phase was washed with water $(3 \times 20 \mathrm{~mL})$, dried over anhydrous $\mathrm{MgSO}_{4}$, filtered and concentrated under vacuum. The residue was purified by column chromatography on silica gel with dichloromethane/hexane 8:2 as eluent to afford the sulfide. The $\mathbf{9 - 1 5}$ heterocycles were obtained similarly, using various derivatives of 2-bromopyridine (6-methyl-, 5-methyl, 4-methyl- for 9, 10, 11, respectively) or benzenethiol (4-methyl-, 4-tert-butyl-, 4-bromo-, 4-nitro- for 12, 13, 14, 15, respectively). The yields were as follows: $8-78 \%, 9-82 \%, 10$ $75 \%, 11-88 \%, 12-79 \%, 13-77 \%, 14-72 \%, 15-70 \%$. The ${ }^{1} \mathrm{H},{ }^{13} \mathrm{C}$ and ${ }^{15} \mathrm{~N} N M R$ spectra of 8 and 12-15 were already reported and assigned in our recent paper [23], while those of 9-11 are described in Supplementary Data (Figures S1-S12). 


\subsubsection{General Procedure for the Synthesis of $\mathrm{Au}$ (III) Trichloride Complexes 8a-15a}

A total of $1 \mathrm{mmol}$ of $\mathrm{NaAuCl}_{4}$ in $18 \mathrm{~mL}$ of water was added to $1 \mathrm{mmol}$ of the corresponding ligand 8-15 in $30 \mathrm{~mL}$ of methanol and stirred at $50{ }^{\circ} \mathrm{C}$ for $24 \mathrm{~h}$. The yellow/orange/red crystals were filtered on a Büchner funnel and dried on air. This method produced $\mathrm{Au}(\mathrm{III})$ trichloride complexes $\mathbf{8 a} \mathbf{a}-\mathbf{1 5 a}$ with the following yields: $\mathbf{8 a}-78 \%, \mathbf{9 a}-$ $86 \%, 10 a-88 \%, 11 a-86 \%, 12 a-69 \%, 13 a-79 \%, 14 a-77 \%, 15 a-72 \%$. The ${ }^{1} \mathrm{H},{ }^{13} \mathrm{C}$ and ${ }^{15} \mathrm{~N}$ NMR spectra of $\mathbf{8 a}$ and $\mathbf{1 2 a}-\mathbf{1 5 a}$ were already reported and assigned in our recent paper [23], while those of 9a-11a are given in Supplementary Data (Figures S13-S18).

\subsubsection{General Procedure for the Synthesis of Tetrachloroaurate(III) Salts $\mathbf{8 b}-\mathbf{1 5 b}$}

The $0.20 \mathrm{mmol}$ of the corresponding $\mathrm{Au}(\mathrm{III})$ trichloride complex $\mathbf{8} \mathbf{a}-\mathbf{1 5} \mathbf{a}$ was placed in one-neck RBF under vacuum $(0.1 \mathrm{~mm} \mathrm{Hg})$ and heated at certain temperature $\left(8 \mathrm{a}-180^{\circ} \mathrm{C}\right.$, 9a-150 ${ }^{\circ} \mathrm{C}, \mathbf{1 0 a}-190{ }^{\circ} \mathrm{C}, \mathbf{1 1 a}-180{ }^{\circ} \mathrm{C}, \mathbf{1 2 a}-165{ }^{\circ} \mathrm{C}, \mathbf{1 3 a}-170{ }^{\circ} \mathrm{C}, \mathbf{1 4 a}-195{ }^{\circ} \mathrm{C}, \mathbf{1 5 a}-190$ $\left.{ }^{\circ} \mathrm{C}\right)$ for $6 \mathrm{~h}$. Then, the resulting solid mixture was allowed to cool to room temperature and washed with $\mathrm{CHCl}_{3}$. The solid residue was dissolved in $\mathrm{MeOH}$ and filtered, and the solvent removed under reduced pressure. This method produced tetrachloroaurate(III) salts $\mathbf{8 b}-\mathbf{1 5} \mathbf{b}$ with the following yields: $\mathbf{8 b}-69 \%, \mathbf{9 b}-54 \%, \mathbf{1 0 b}-71 \%, \mathbf{1 1} \mathbf{b}-82 \%, \mathbf{1 2} \mathbf{b}-$ $66 \%, \mathbf{1 3 b}-75 \%, \mathbf{1 4 b}-53 \%, \mathbf{1 5 b}-65 \%$. The ${ }^{1} \mathrm{H},{ }^{13} \mathrm{C}$ and ${ }^{15} \mathrm{~N}$ NMR spectra of $\mathbf{8 b}-\mathbf{1 5 b}$ are given in Supplementary Data (Figures S19-S43).

\subsection{Studies Of Catalytic Properties of $\mathbf{8 b} \mathbf{- 1 5 b}$}

A mixture of catalyst (8b-15b, $0.01 \mathrm{mmol})$, benzaldehyde 19 (106 mg, i.e., $1.0 \mathrm{mmol})$, piperidine 20 (93.7 mg, i.e., $1.1 \mathrm{mmol}$ ) and phenylacetylene 18 (153 mg, i.e., $1.5 \mathrm{mmol})$ was stirred at $40-55{ }^{\circ} \mathrm{C}$ for $24-48 \mathrm{~h}$. The yields of 19 conversions were determined by ${ }^{1} \mathrm{H}$ NMR analysis of crude reaction mixtures, using 10.05 and 4.83 ppm signals integration areas.

\subsection{Metabolic Activity Assay}

The MTT (3-(4,5-dimethyldiazol-2-yl)-2,5 diphenyl tetrazolium bromide) assay, which measures activity of cellular dehydrogenases, was used to determine the cytotoxicity of new compounds [22]. In brief, cells were seeded on 96-well plates in $100 \mu \mathrm{L}$ of culture medium and left to grow for $24 \mathrm{~h}$. Tested compounds were dissolved in DMSO and diluted with the complete culture medium. To each well, $100 \mu \mathrm{L}$ of such prepared dilution was added to obtain concentration range from $10^{-7}$ to $10^{-3} \mathrm{M}$. After $24 \mathrm{~h}$ of treatment, MTT ( $5 \mathrm{mg} / \mathrm{mL}$ in PBS) was added, and cells were incubated for an additional $2 \mathrm{~h}$. Then, the medium was removed and insoluble blue formazan crystals were dissolved in $100 \mu \mathrm{L}$ of DMSO. The absorbance of the formazan product was measured at $540 \mathrm{~nm}$ using FlexStation 3 Multi-Mode Microplate Reader (Molecular Devices, LLC., San Jose, CA, USA). The untreated cells were used as a control. The data were expressed as mean \pm SEM of three independent experiments.

\section{Results and Discussion}

\subsection{Synthesis and Characterization}

Herein, we report that the $\mathrm{C}-\mathrm{H}$ activation with the formation of intramolecular $s p^{2} \mathrm{C}$ $s p^{2} \mathrm{~N}$ bond can be conducted in solvent-free conditions, just by heating the $\mathrm{Au}(\mathrm{III}) \sigma-$ complexes 8a-15a below the particular melting point.

In the first step, we have prepared a series of 2-phenylsulfanylpyridine ligands 8-15 and transformed them into the $\mathrm{Au}(\mathrm{III})$ trichloride complexes $\mathbf{8 a}-\mathbf{1 5 a}$ by the methodology presented previously by Fuchita et al. [24], and later modified in our research group (Scheme 4) [23]; the details of these syntheses are given below. 


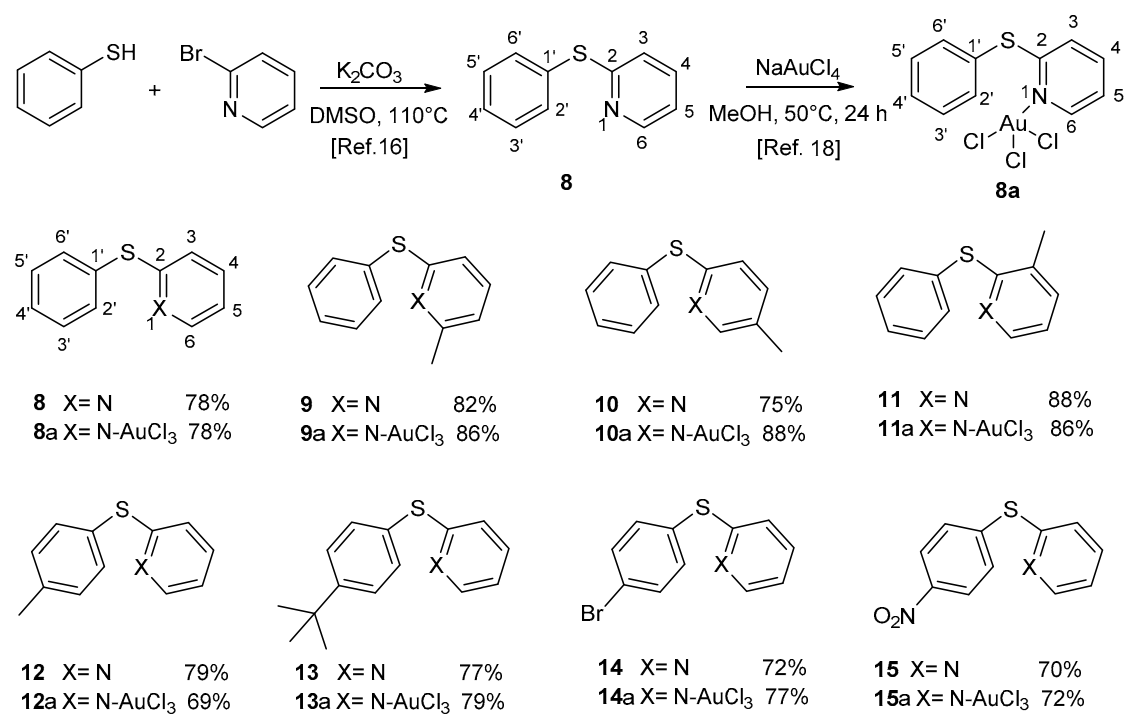

Scheme 4. Structures of ligands 8-15 and $\mathrm{Au}(\mathrm{III})$ trichloride complexes 8a-15a.

The species $8, \mathbf{1 2 - 1 5}$ and $\mathbf{8 a}, \mathbf{1 2 a}-\mathbf{1 5 a}$ were already spectroscopically $\left({ }^{1} \mathrm{H},{ }^{13} \mathrm{C},{ }^{15} \mathrm{~N}\right.$ NMR), and structurally (single crystal X-ray study of 8a-DUCYEI and 14a-DUCYIM) [21] characterized [22], while the data of $\mathbf{9 - 1 1}$ and $\mathbf{9 a - 1 1 a}$ are described in Supplementary Data (Figures S1-S18).

In the second step, the $\mathrm{Au}(\mathrm{III})$ trichloride complexes 8a-15a were converted via heating to the corresponding tetrachloroaurate(III) salts $\mathbf{8 b} \mathbf{- 1 5} \mathbf{b}$, which contain heterocyclic cations analogous to those of $\mathbf{6 x}$ and $\mathbf{6 y}$, described by Kim et al. [21]. This procedure was effective for the simplest complex $\mathbf{8 a}$ and its analogues, based on substrates functionalized on either the pyridine or the phenyl ring (9a-11a and 12a-15a, respectively; Scheme 5). It was successfully applied in the gram-scale synthesis of $8 \mathbf{b}(1 \mathrm{mmol})$, leading to $86 \%$ yield of the corresponding product. The spectroscopic characterization $\left(\mathrm{IR},{ }^{1} \mathrm{H},{ }^{13} \mathrm{C},{ }^{15} \mathrm{~N} N M R\right)$ of $8 \mathbf{b}-$ $\mathbf{1 5 b}$ is given in Supplementary Data (Figures S19-S43). We assume that the mechanism of $\mathbf{8 a}$ $\rightarrow \mathbf{8 b}$ reaction includes the formation of the intermediate $\mathrm{Au}(\mathrm{III})$ dichloride organometallic 16 (following $\mathrm{HCl}$ elimination), which is transformed to the heterocyclic cation present in the tetrachloroaurate(III) salt $\mathbf{8 b}$. Moreover, a part of $\mathbf{8 a}$ is also decomposed to the 2-phenylsulfanylpyridine ligand 8.

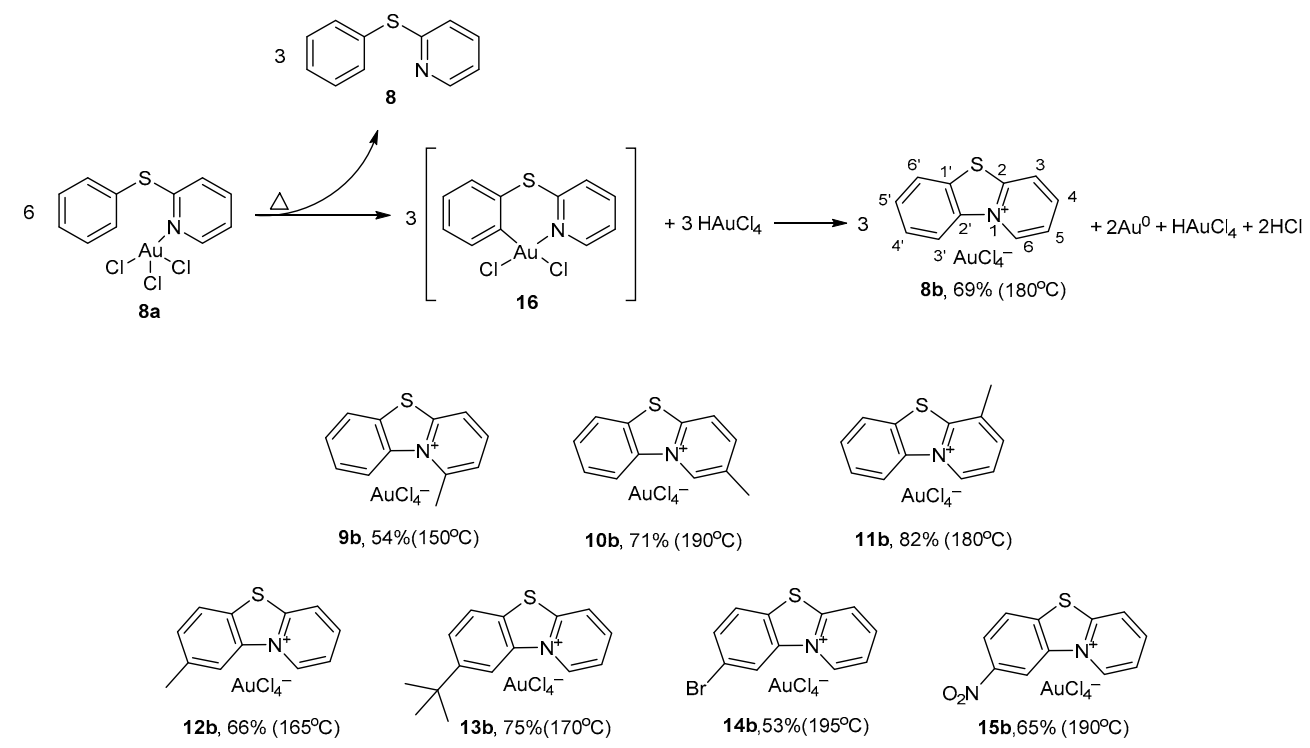

Scheme 5. Structures of tetrachloroaurate(III) salts $\mathbf{8 b}-\mathbf{1 5 b}$ containing heterocyclic cations obtained by the thermally induced $\mathrm{C}-\mathrm{H}$ activation. 
The elimination of compound 8 was confirmed by thermogravimetric analysis TGADTA. Upon heating when the temperature reached ca. $180{ }^{\circ} \mathrm{C}$, the complex 8a decomposed in two steps. The first degradation step, ca. $31 \%$ decrease of weight, indicated the 8a $\rightarrow \mathbf{8}$ reaction. Next, at elevated temperature, the second step revealed the elimination of $\mathrm{HAuCl}_{4}$ species (Figure 1).

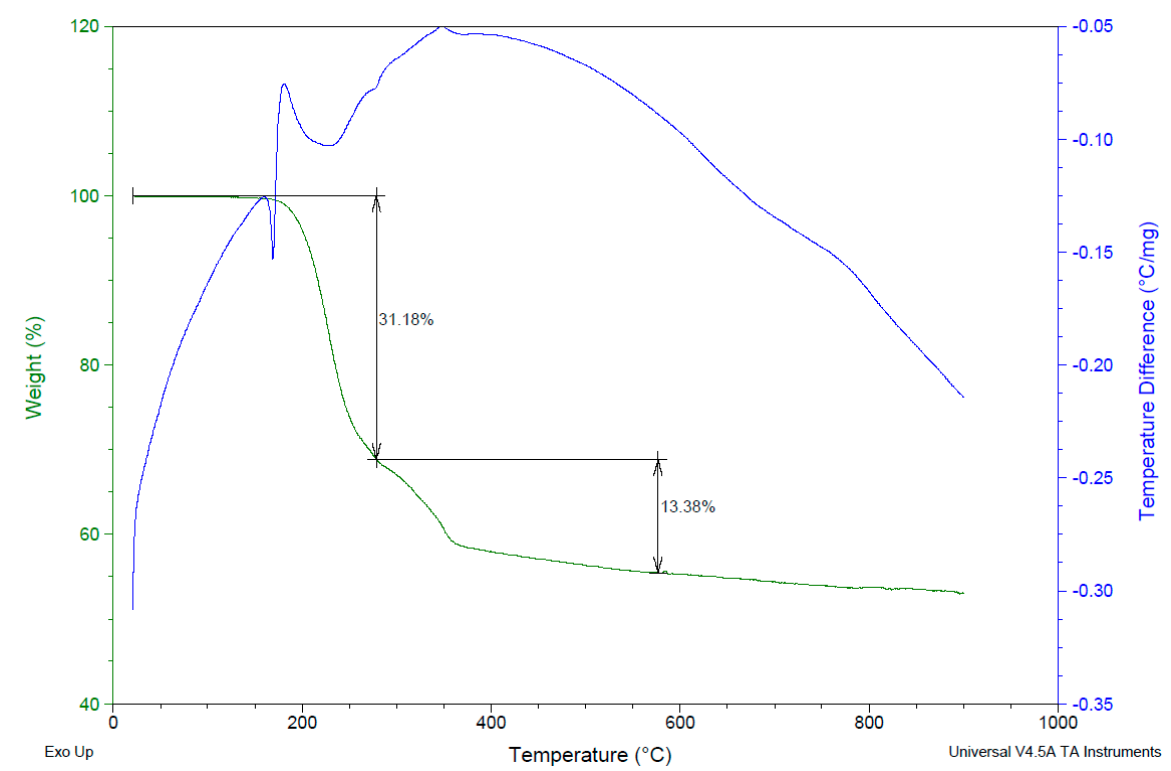

Figure 1. TGA-DTA analysis of the Au(III) trichloride complex 8a.

The analogous reactions $\mathbf{9 a - 1 5 a} \rightarrow \mathbf{9 b}-\mathbf{1 5 b}$ occur probably according to the same mechanism.

The assumed structural formulae of the cations present in the $\mathbf{8 b}-\mathbf{1 5 b}$ salts are in agreement with the fully assigned (by ${ }^{1} \mathrm{H}-{ }^{13} \mathrm{C}$ and ${ }^{1} \mathrm{H}-{ }^{15} \mathrm{~N}$ HMQC/HMBC techniques) NMR spectra. The respective ${ }^{1} \mathrm{H},{ }^{13} \mathrm{C}$ and ${ }^{15} \mathrm{~N}$ chemical shifts, and the comparison of these chemical shifts to those for the corresponding parent heterocycles $\mathbf{8 - 1 5}$, allows us to determine the relevant differences, which reveal characteristic patterns similar for all studied cations thus, confirming their analogous structures (Tables S7-S9, part S2, Supplementary Data).

The most characteristic phenomenon is large deshielding (by ca. 0.4-2.2 ppm) of all heterocyclic protons, expressed especially for the $\mathrm{H}(3)$ and $\mathrm{H}\left(3^{\prime}\right)$ atoms $\left(\Delta^{1 \mathrm{H}}=\right.$ ca. 1.6-2.2 ppm and ca. 1.3-1.7 ppm, respectively), as well as for the nitrogen-adjacent $\mathrm{H}(6)$ proton $\left(\Delta^{1 \mathrm{H}}=\right.$ ca. $\left.1.6-1.9 \mathrm{ppm}\right)$; in the latter case this effect results in unusually high $\delta_{\text {cat }}{ }^{1 \mathrm{H}}$ values (>10 ppm).

The heterocyclic carbons are either deshielded $\left(\mathrm{C}(3), \mathrm{C}(4), \mathrm{C}(5), \mathrm{C}\left(2^{\prime}\right)\right)$ or shielded $(\mathrm{C}(2)$, $\left.\mathrm{C}(6), \mathrm{C}\left(1^{\prime}\right), \mathrm{C}\left(3^{\prime}\right), \mathrm{C}\left(6^{\prime}\right)\right)$, but also nearly unaffected $\left(\mathrm{C}\left(4^{\prime}\right), \mathrm{C}\left(5^{\prime}\right)\right)$. The heterocyclic nitrogens are significantly shielded (by ca. $89-92$ ppm), this effect reflecting their quaternary character $\left(=\mathrm{N}<^{+}\right)$.

The ${ }^{1} \mathrm{H}-{ }^{13} \mathrm{C}$ long-range (via two or three bonds) correlations inside the pyridine or phenyl moieties, exhibited by the ${ }^{1} \mathrm{H}-{ }^{13} \mathrm{C}$ HMBC spectra of the $\mathrm{Au}(\mathrm{III})$ trichloride complexes $\mathbf{8 a - 1 5 a}$ and the cations present in the tetrachloroaurate(III) salts $\mathbf{8 b} \mathbf{b} \mathbf{- 1 5} \mathbf{b}$, are typical for such six-membered aromatic rings, and are analogous to those recently reported for the heterocycles 8 and 12-15 [23] (and presently for 9-11).

However, in case of $\mathbf{8 b}$ and $\mathbf{1 0 b}-\mathbf{1 5 b}$ also, another correlation between $\mathrm{H}(6)$ and $\mathrm{C}\left(2^{\prime}\right)$ atoms (via three bonds) is observed, exhibiting the presence of the new $\mathrm{N}(1)-\mathrm{C}\left(2^{\prime}\right)$ bonding (obviously, it is not observed for $\mathbf{9 b}$ which has no $\mathrm{H}(6)$ proton); otherwise, i.e., if this additional connection between pyridine and phenyl rings was absent, there would be no possibility for any ${ }^{1} \mathrm{H}-{ }^{3} \mathrm{C}$ spin-spin interactions involving $\mathrm{H}(6)$ and $\mathrm{C}\left(2^{\prime}\right)$. This $\mathrm{H}(6)-\mathrm{C}\left(2^{\prime}\right)$ correlation, being a crucial proof for the tricyclic structure of the cations present in $\mathbf{8 b}-\mathbf{1 5 b}$ 
salts, has been graphically emphasized (with a circle and an arrow) at the respective ${ }^{1} \mathrm{H}-{ }^{13} \mathrm{C}$ HMBC spectra, reprinted in Supplementary Data (Figures S21, S28, S31, S34, S37, S40, S43).

Additionally, the presence of tetrachloroaurate(III) counterions in the salts $\mathbf{8 b} \mathbf{\mathbf { 1 5 }} \mathbf{\mathbf { b }} \mathbf{b}$ was confirmed by far-IR spectra. One strong band at 350-355 $\mathrm{cm}^{-1}$ (exemplified for $\mathbf{8 b}$ at Figure 2; see also Supplementary Data, Schemes S7-S14) and corresponds to the wellknown asymmetric $\mathrm{Au}-\mathrm{Cl}$ stretching vibration in the $\mathrm{AuCl}_{4}{ }^{-}$anion [25].

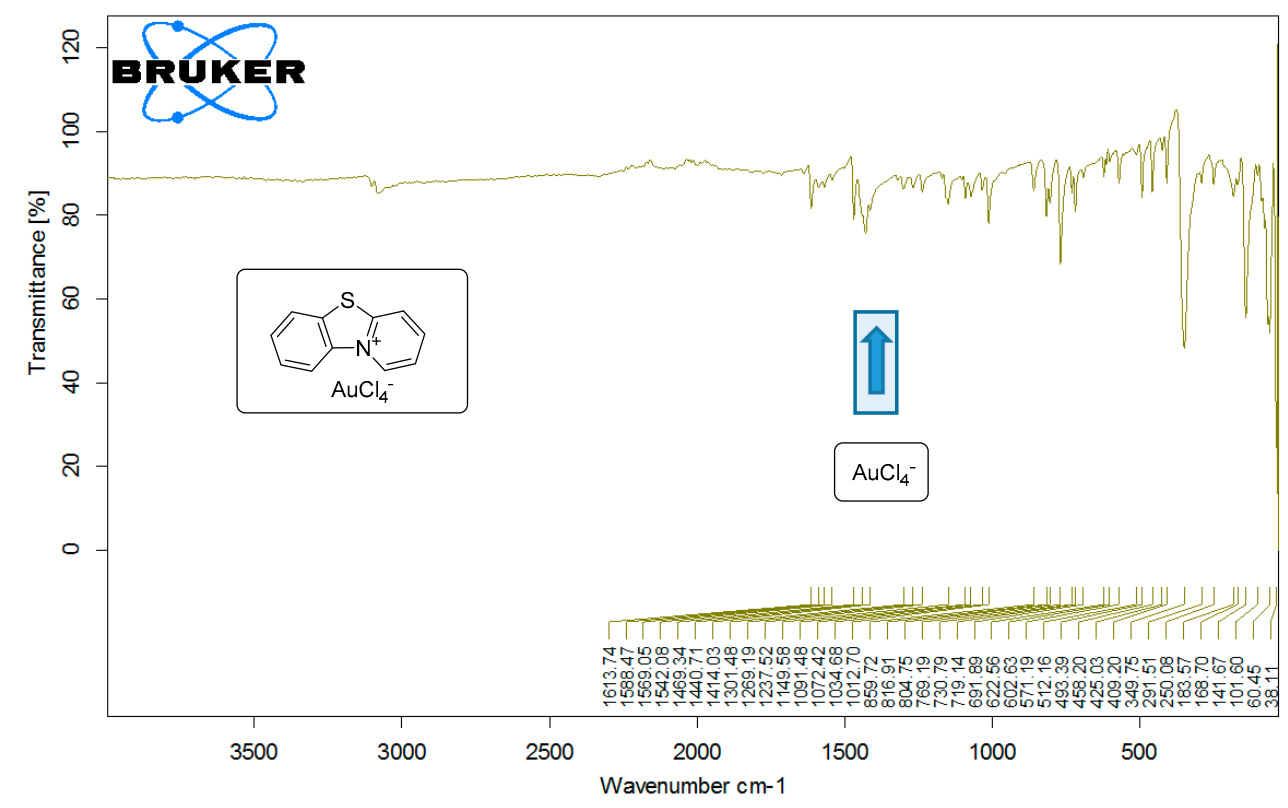

Figure 2. Far-IR spectrum of the tetrachloroaurate(III) salt $8 \mathbf{b}$.

Moreover, the mass spectrum of the tetrachloroaurate(III) salt $\mathbf{8 b}$ exhibits the main peak at 186.1, which corresponds well to that calculated for the respective heterocyclic cation $\mathrm{C}_{11} \mathrm{H}_{8} \mathrm{AuCl}_{4} \mathrm{NS}^{+}$(186.0; see Supplementary Data, Figure S22).

\subsection{Catalytic Properties}

In the past, some $\mathrm{Au}(\mathrm{III})$-salen complexes and the $\left[\mathrm{Au}^{\mathrm{III}}\left(2\right.\right.$-phenylpyridine $\left.{ }^{*}\right) \mathrm{Cl}_{2}$ ] organometallic were exhibited to catalyze three-component coupling reactions between aldehydes, amines and alkynes with high yields; when chiral prolinol derivatives were used as substrates, excellent diastereoselectivities were reached (up to 99:1) [26,27]. Similarly, we have recently observed high catalytic activity of the $\mathrm{Au}(\mathrm{III})$ trichloride complexes 8a and 12a-15a in the coupling reaction between phenylacetylene 18, benzaldehyde 19 and piperidine 20, to form 1-(1,3-diphenylprop-2-yn-1-yl)piperidine 21 (yields 84-99\%) (Scheme 6) [23].

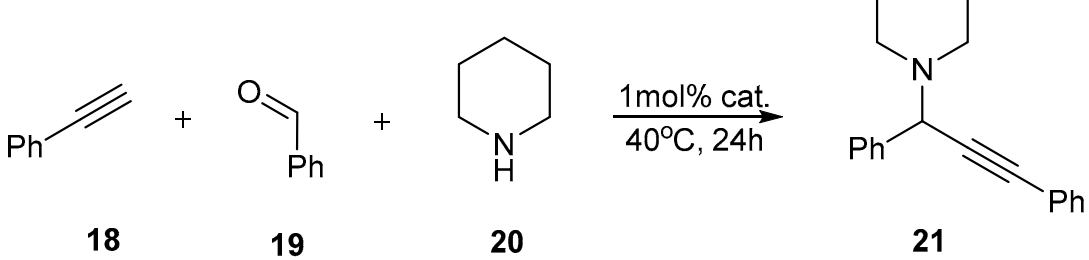

Scheme 6. The coupling reaction between phenylacetylene 18, benzaldehyde 19 and piperidine 20.

The above facts prompted us to evaluate the catalytic properties of the presently studied tetrachloroaurate(III) salts $\mathbf{8 b}-\mathbf{1 5 b}$, in the same $\mathbf{1 8}+\mathbf{1 9}+\mathbf{2 0}$ three-component reaction; the yields at $55{ }^{\circ} \mathrm{C}$ were as high as $97-99 \%$ (Table 1). It is worth noting, that lowering 
the temperature to $40{ }^{\circ} \mathrm{C}$ resulted in a significant yield decrease, below $70 \%$-as exemplified by the species $\mathbf{1 5 b}$. The same reaction catalyzed by sodium tetrachloroaurate(III) enabled us to obtain the final piperidine derivative, yet the yield was lower than for the used catalysts $\mathbf{8 b} \mathbf{- 1 5} \mathbf{b}$. This indicates that the presence of the organic cation enhances the reactions efficiency.

Table 1. Yields of three-component reaction between phenylacetylene, benzaldehyde and piperidine catalyzed by tetrachloroaurate(III) salts $\mathbf{8 b} \mathbf{- 1 5}$.

\begin{tabular}{cccc}
\hline Catalyst & $\mathbf{t}[\mathbf{h}]$ & $\mathbf{T}\left[{ }^{\circ} \mathbf{C}\right]$ & Yield [\%] \\
\hline $\mathbf{8 b}$ & 24 & 55 & 99 \\
$\mathbf{9 b}$ & 24 & 55 & 97 \\
$\mathbf{1 0 b}$ & 24 & 55 & 97 \\
$\mathbf{1 1 b}$ & 24 & 55 & 99 \\
$\mathbf{1 2 b}$ & 24 & 55 & 99 \\
$\mathbf{1 3 b}$ & 24 & 55 & 99 \\
$\mathbf{1 4 b}$ & 24 & 55 & 98 \\
$\mathbf{1 5 b}$ & 24 & 40 & 58 \\
$\mathbf{1 5 b}$ & 48 & 40 & 66 \\
$\mathbf{1 5 b}$ & 24 & 55 & 99 \\
$\mathbf{N a A u C l}$ & 24 & 55 & 84 \\
\hline
\end{tabular}

In the next step, using catalyst $\mathbf{8 b}$, we tested various aldehydes ( $p$-anisaldehyde $\mathbf{2 2}$, 4-(trifluoromethyl) benzaldehyde 23, cyclohexanecarboaldehyde 24) and amines (pyrrolidine 25, morpholine 26, dibutylamine 27) for three-component reactions. Corresponding products 28-33 were obtained with very high yields (Scheme 7).<smiles>C#C[P+]([CH2+])c1ccccc1</smiles>
28, $97 \%$<smiles>C(#Cc1ccccc1)c1ccccc1</smiles>

$31,97 \%$

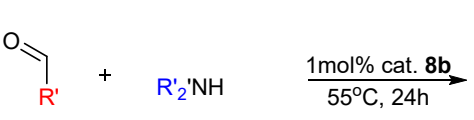

19, 22--24 20, 25--27<smiles>FC(F)(F)c1ccc(C(C#Cc2ccccc2)N2CCCCC2)cc1</smiles>
29, $99 \%$<smiles>C(#CC(c1ccccc1)N1CCCC1)c1ccccc1</smiles>

$32,99 \%$<smiles>[R]C(C#Cc1ccccc1)N([R])[R]</smiles><smiles>C(#CC(C1CCCCC1)N1CCCCC1)c1ccccc1</smiles>

30, $99 \%$<smiles>CCCCCN(CCCC)C(C#Cc1ccccc1)c1ccccc1</smiles>

33, $76 \%$

Scheme 7. The coupling reaction between phenylacetylene 18 and adlehydes 19, 22-24 and amines 20, 25-27.

\subsection{Biological Activity}

Due to the known anticancer properties of $\mathrm{Au}(\mathrm{I})$ and $\mathrm{Au}(\mathrm{III})$ complexes, or organometallics, e.g., with thiolates, thioureas, N-heterocyclic carbines, phosphanes and alkynes [28], the in vitro cytotoxicity of the tetrachloroaurate(III) salts $\mathbf{8 b} \mathbf{b} \mathbf{- 1 5} \mathbf{b}$ was tested against leukemia HL-60 and breast cancer MCF-7 cell lines. The cells were exposed to the increasing concentrations of analogues for $48 \mathrm{~h}$ and investigated using conventional MTT assay [29]. Cisplatin was used as a positive control. The most cytotoxic on both cell lines was $\mathbf{1 3 b}$, with the half maximal inhibitory concentration $\left(\mathrm{IC}_{50}\right)$ of $20.9 \pm 0.9$ and $16.9 \pm 0.8 \mu \mathrm{M}$ on HL-60 and MCF-7 cells, respectively (Table 2). In MCF-7 cells this compound exhibited 1.4-fold 
higher inhibitory activity than Cisplatin. Two most cytotoxic for MCF-7 cells compounds, $\mathbf{1 2 b}$ and 13b, were also tested on a non-tumorigenic MCF-10A cell line, to evaluate their influence on normal cells. Analogue 12b was equally active on MCF-7 and MCF-10A cells, while $\mathbf{1 3 b}$ was 1.2-fold less toxic for normal than for breast cancer cells.

Table 2. Cytotoxic activity of tetrachloroaurate(III) salts $\mathbf{8 b}-\mathbf{1 5 b}$.

\begin{tabular}{ccccc}
\hline & \multicolumn{3}{c}{ IC $_{\mathbf{5 0}}[\boldsymbol{\mu M}]^{\mathbf{a}}$} \\
\cline { 2 - 5 } Compound & HL-60 & MCF-7 & MCF-10A & $\begin{array}{c}\text { Selectivity Index } \\
\text { MCF-10A/MCF-7 }\end{array}$ \\
\cline { 2 - 5 } $\mathbf{8 b}$ & $>100$ & $>100$ & \\
$\mathbf{9 b}$ & $42.7 \pm 1.4$ & $76.9 \pm 4.4$ & & \\
$\mathbf{1 0 b}$ & $>100$ & $71.6 \pm 6.7$ & & \\
$\mathbf{1 1 b}$ & $36.5 \pm 2.2$ & $74.0 \pm 0.3$ & & 1.02 \\
$\mathbf{1 2 b}$ & $41.2 \pm 1.8$ & $21.3 \pm 2.0$ & $21.8 \pm 2.3$ & \\
$\mathbf{1 3 b}$ & $20.9 \pm 0.9$ & $16.9 \pm 0.8$ & $20.7 \pm 0.5$ & \\
$\mathbf{1 4 b}$ & $75.8 \pm 6.8$ & $41.5 \pm 1.7$ & & \\
15b & $>100$ & $>100$ & & \\
Cisplatin & $4.9 \pm 0.1$ & $23.6 \pm 1.3$ & & \\
\hline
\end{tabular}

$\bar{a}$ Compound concentration required to inhibit metabolic activity by $50 \%$. Data are expressed as the mean \pm SEM from the concentration response curves of at least three experiments.

\section{Conclusions}

In this article we present the first thermal C-N bond formation supported by $\mathrm{Au}(\mathrm{III})$ salts, performed in solvent-free conditions. This type of cross dehydrogenative coupling amination is one of the first examples efficiently conducted using gold complexes. The structure of the obtained compounds was confirmed by ${ }^{1} \mathrm{H},{ }^{13} \mathrm{C},{ }^{15} \mathrm{~N}$ NMR, TGA-DTA, and ATR/FT-IR analysis with a detailed discussion concerning the differences in the chemical shifts of cations in salts and their parent ligands. The mechanism of the reaction was also investigated and indicated the formation of a metallacycle as an intermediate. Additionally, all $\mathrm{Au}$ (III) salts were tested as catalysts in a multicomponent synthesis of propargylic amine. The reaction was almost quantitative in each case. We observed that organic cation enhanced the efficiency of the reaction. The anticancer activity was evaluated, showing a promising antiproliferative potential of the tert-butyl salt.

Supplementary Materials: The following are available online at https://www.mdpi.com/article/10 $.3390 / \mathrm{ma14071676/s1}$. Yields, melting points, elemental analysis, ${ }^{1} \mathrm{H},{ }^{13} \mathrm{C},{ }^{15} \mathrm{~N}$ and ${ }^{1} \mathrm{H}-{ }^{13} \mathrm{C} \mathrm{HMBC}$ NMR spectra of A. Ligands 9-11 (Figures S1-S12), B. Au(III) trichloride complexes 9a-11a (Figures S13-S18), C. Tetrachloroaurate(III) salts $\mathbf{8 b - 1 5 b}$ (Figures S19-S43), and ${ }^{1} \mathrm{H},{ }^{13} \mathrm{C}$ and ${ }^{15} \mathrm{~N}$ NMR assignments for 9a-11a, based on ${ }^{1} \mathrm{H}_{-}{ }^{13} \mathrm{C}$ HSQC, HMBC and ${ }^{1} \mathrm{H}^{-15} \mathrm{~N}$ HMBC, and differences between ${ }^{1} \mathrm{H},{ }^{1} 3 \mathrm{C}$ or ${ }^{15} \mathrm{~N}$ chemical shifts for the same atom in the molecules of complexes $9 \mathbf{a}-\mathbf{1 1 a}$ and ligands 9-11 are presented (Tables S1-S6). Additionally, ${ }^{1} \mathrm{H},{ }^{13} \mathrm{C}$ and ${ }^{15} \mathrm{~N}$ chemical shifts of salts $\mathbf{8 b} \mathbf{b} \mathbf{- 1 5} \mathbf{b}$ and parent heterocycles 8-15 are presented (Tables S7-S9).

Author Contributions: Conceptualization, J.Ś; data curation, J.M. and J.D.-S.; formal analysis, J.M., A.J.P.-M., L.P. and J.D.-S.; supervision, A.E.J. and J.S.; Writing-original draft, J.M., A.J.P.-M., L.P. and A.E.J.; Writing — review \& editing, J.Ś. All authors have read and agreed to the published version of the manuscript.

Funding: This research received no external funding.

Institutional Review Board Statement: Not applicable.

Informed Consent Statement: Not applicable.

Data Availability Statement: Not applicable.

Conflicts of Interest: The authors declare no conflict of interest. 


\section{References}

1. Labinger, J.A.; Bercaw, J.E. Understanding and exploiting C-H bond activation. Nature 2002, 417, 507-514. [CrossRef] [PubMed]

2. Wencel-Delord, J.; Droge, T.; Liu, F.; Glorius, F. Towards mild metal-catalyzed C-H bond activation. Chem. Soc. Rev. 2011, 40, 4740-4761. [CrossRef] [PubMed]

3. Albrecht, M. Cyclometalation Using d-Block Transition Metals: Fundamental Aspects and Recent Trends. Chem. Rev. 2010, 110, 576-623. [CrossRef]

4. Meera, G.; Rohit, K.R.; Susan Treesa, G.S.; Anilkumar, G. Advances and Prospects in Gold-Catalyzed C-H Activation. Asian J. Org. Chem. 2020, 9, 144-161. [CrossRef]

5. Zhang, Y.-H.; Shi, G.-F.; Yu, J.-Q. Carbon-carbon r-bond formation via C-H bond functionalization. In Comprehensive Organic Synthesis, 2nd ed.; Elsevier: Amsterdam, The Netherlands, 2014; pp. 1101-1209.

6. Xie, J.; Zhu, C. Sustainable C(sp3 )-H Bond Functionalization; Springer: Heidelberg, Germany, 2016.

7. Rej, S.; Das, A.; Chatani, N. Strategic evolution in transition metal-catalyzed directed C-H bond activation and future directions. Coord. Chem. Rev. 2021, 431, 213683-213719. [CrossRef]

8. Borpatra, P.J.; Deka, B.; Deb, M.L.; Baruah, P.K. Recent advances in intramolecular C-O/C-N/C-S bond formation via C-H functionalization. Org. Chem. Front. 2019, 6, 3445-3489. [CrossRef]

9. Kumar, R.; Nevado, C. Cyclometalated Gold(III) Complexes: Synthesis, Reactivity, and Physicochemical Properties. Angew. Chem. Int. Ed. 2017, 56, 1994-2015. [CrossRef]

10. Corma, A.; Leyva-Perez, A.; Sabater, M.J. Gold-Catalyzed Carbon-Heteroatom Bond-Forming Reactions. Chem. Rev. 2011, 111, 1657-1712. [CrossRef]

11. Li, Z.; Brouwer, C.H.; He, C.H. Gold-Catalyzed Organic Transformations. Chem. Rev. 2008, 108, 3239-3265.

12. Constable, E.C.; Leese, T.A. Cycloaurated derivatives of 2-phenylpyridine. J. Organomet. Chem. 1989, 363, 419-424. [CrossRef]

13. Stoccoro, S.; Alesso, G.; Cinellu, M.A.; Minghetti, G.; Zucca, A.; Manassero, M.; Manassero, C. Reactivity of 1,3-bis(2pyridyl)benzene, $\mathrm{N} \wedge \mathrm{CH} \wedge \mathrm{N}$, with gold(iii) chlorides: Salts, adducts and cyclometalated pincer derivatives. Crystal and molecular structures of $\left[\mathrm{HN}_{\curlywedge} \mathrm{CH}_{\curlywedge} \mathrm{N}\right]\left[\mathrm{AuCl}_{4}\right],\left[\mathrm{Au}\left(\mathrm{N}_{\curlywedge} \mathrm{C}_{\curlywedge} \mathrm{N}\right) \mathrm{Cl}\right]\left[\mathrm{PF}_{6}\right]$ and $\left[\mathrm{Au}\left(\mathrm{N}_{\curlywedge} \mathrm{C}_{\curlywedge} \mathrm{N}\right) \mathrm{Cl}\left(\mathrm{PPh}_{3}\right)_{2}\right]\left[\mathrm{PF}_{6}\right]$. Dalton Trans. 2009, 18, 3467-3477.

14. Mori, S.; Osuka, A. Aromatic and Antiaromatic Gold(III) Hexaphyrins with Multiple Gold-Carbon Bonds. J. Am. Chem. Soc. 2005, 127, 8030-8031. [CrossRef]

15. Louillat, M.-L.; Patureau, F.W. Oxidative C-H amination reactions. Chem. Soc. Rev. 2014, 43, 901-910. [CrossRef]

16. Tsang, W.C.P.; Zheng, N.; Buchwald, S.L. Combined C-H Functionalization/C-N Bond Formation Route to Carbazoles. J. Am. Chem. Soc. 2005, 127, 14560-14561. [CrossRef]

17. Wang, H.; Wang, Y.; Peng, C.; Zhang, J.; Zhu, Q.A. Direct Intramolecular C-H Amination Reaction Cocatalyzed by Copper(II) and Iron(III) as Part of an Efficient Route for the Synthesis of Pyrido[1,2-a]benzimidazoles from N-Aryl-2-aminopyridines. J. Am. Chem. Soc. 2010, 132, 13217-13219.

18. Hu, J.; Chen, S.; Sun, Y.; Yang, J.; Rao, Y. Synthesis of Tri- and Tetrasubstituted Pyrazoles via Ru(II) Catalysis: Intramolecular Aerobic Oxidative C-N Coupling. Org. Lett. 2012, 14, 5030-5033.

19. Wang, X.; Jin, Y.; Zhao, Y.; Zhu, L.; Fu, H. Copper-Catalyzed Aerobic Oxidative Intramolecular C-H Amination Leading to Imidazobenzimidazole Derivatives. Org. Lett. 2012, 14, 452-455.

20. Nadres, E.T.; Daugulis, O. Heterocycle Synthesis via Direct C-H/N-H Coupling. J. Am. Chem. Soc. 2012, 134, 7-10. [CrossRef] [PubMed]

21. Kim, J.H.; Mertens, R.T.; Agarwal, A.; Parkin, S.; Berger, G.; Awuah, S.G. Direct intramolecular carbon( $\left.\mathrm{sp}^{2}\right)-$ nitrogen(sp $\left.{ }^{2}\right)$ reductive elimination from gold(III). Dalton Trans. 2019, 48, 6273-6282.

22. Cambridge Crystallographic Database. Available online: https:/ /www.ccdc.cam.ac.uk/structures/ (accessed on 7 May 2019 ).

23. Mruk, J.; Pazderski, L.; Ścianowski, J.; Wojtczak, A. Structural and NMR spectroscopic studies of 2-phenylsulfanylpyridine and its analogues or derivatives, and their Au(III) chloride complexes. Inorg. Chim. Acta 2020, 500, 119182.

24. Fushita, Y.; Ieda, H.; Kayama, A.; Kinoshita-Nagaoka, J.; Kawano, H.; Kameda, S.; Mikuriya, M. Cycloauration of 2-substituted pyridine deivatives. Synthesis, structure and reactivity of six-membered cycloaurated complexes od 2-anilino-, 2-phenoxy- and 2-(phenylsulfanyl)-pyridine. J. Chem. Soc. Dalton Trans. 1998, 4095-4100. [CrossRef]

25. McConnell, A.A.; Brown, D.H.; Smith, W.E. The vibrational properties of some gold(III)-halide complexes. Spectrochimica Acta 1981, 37, 583-585. [CrossRef]

26. Lo, V.K.-Y.; Liu, Y.; Wong, M.-K.; Che, C.-M. Gold(III) Salen Complex-Catalyzed Synthesis of Propargylamines via a ThreeComponent Coupling Reaction. Org. Lett. 2006, 8, 1529-1532.

27. Lo, V.K.-Y.; Kung, K.K.-Y.; Wong, M.-K.; Che, C.-M. Gold(III) (C`N) complex-catalyzed synthesis of propargylamines via a three-component coupling reaction of aldehydes, amines and alkynes. J. Organomet. Chem. 2009, 694, 583-591.

28. Zhang, J.; Zhang, B.; Li, X.; Han, X.; Liu, R.; Fang, J. Small molecule inhibitors of mammalian thioredoxin reductase as potential anticancer agents: An update. Med. Res. Rev. 2019, 39, 5-39. [CrossRef]

29. Mosmann, T. Rapid colorimetric assay for cellular growth and survival: Application to proliferation and cytotoxicity assays. J. Immunol. Methods 1983, 65, 55-63. [CrossRef] 